\title{
Dissecting the Nexus between Sustainable counter insurgency and Sustainable Development Goals: Putting Nigeria in the Context
}

\author{
Popoola Michael A. (PhD), Omosebi Fredrick Adeola
}

\author{
Department of History and International Studies, Babcock University, Ilishan-Remo, Ogun State. \\ Email: popoolam@babcock.edu.ng \\ Department of Businesss Administration and Marketing, Babcock University, Ilishan-Remo, Ogun State \\ Email: omosebifredo@yahoo.com
}

\begin{abstract}
The major objective of the United Nations organization is to foster world peace and security. Asides this, the global body is also concerned with the creation of the enabling environment which will guarantee international socio-economic prosperity for all humans. Hence, the UNO developed the Sustainable Development Goals in September 2015. The agenda was meant to put the whole world on a more prosperous and sustainable path so as to make positive changes for both people and the planet. However, a perennial threat to the realization of this goal in the developing countries, and in Nigeria particularly, is the scourge of insurgency which has grown significantly in sophistication. The continuous terror attacks by Boko Haram insurgent group in Nigerian only confirms the ineffectiveness of the counter-insurgency strategy being used by the government. The research discovered that Boko Haram incessant terror strike shave been threatening almost all the basic issues that constitute the SDGs such as eradication of poverty and hunger, good health, quality education, clean water and sanitation and economic growth among others and made their achievement a mere illusion. Hence, the research proposed that in addition to military approach, a comprehensive strategy such as; addressing the conditions that gave rise to insurgency, application of intelligence, good governance and international cooperation would be required to guarantee sustainable counter-insurgency and pave the way for the achievement of the SDGs in Nigeria. The study adopted analytical and descriptive research design for data collection and analysis. Keywords- Combating, Counter-Insurgency, Development, Military, Sustainable.
\end{abstract}

\section{INTRODUCTION}

The major goal of the United Nations Organization (UNO) is the fostering of global peace and security. But a corollary to the issue of world peace and security is the creation of the enabling environment which will guarantee international socio-economic prosperity. Hence, the global body is also concerned with and committed to the promotion of the welfare of all nations as well as guaranteeing a healthy planet. This desire manifested in the adoption of the Sustainable Development Goals (SDGs) on September 25th 2015. The SDGs area broad and audacious socio-economic blueprint, that serve as a universal call to action for the purpose of addressing some teething socio-economic menace that are plaguing the world. Thus, the 17 core issues which make up the SDGs are an inclusive agenda, expected to work in the spirit of partnership and pragmatism to make the right choices now so as to transform our world and improve life in a sustainable way, for both the present and the future generations (UNO, 2015).

The Agenda offers a unique opportunity to put the whole world on a more prosperous and sustainable development path with the ultimate objective of uniting the world together to make a positive change for both the people and the planet. According to Ban Kimoon, the United Nations Secretary-General from 2007 to 2016, "We don't have plan B because there is no planet B" This implied that human beings must make optimum use of this single planet and make it to work for their progress (UNSG, 2016).This thought has guided the pursuit of the Sustainable Development Goals (SDGs).

One uniqueness of the SDGs is that they cover is sues that affect the entire globe. Their framework does not distinguish between "developed" and "developing" nations, 
and that is why issues about achieving the goals by the set target date of 2030 have been in the front burner of national and global discourses since January 2016.

The 17 goals are as follows:-(1) End poverty in all its forms everywhere, (2) Zero Hunger, (3)Good Health and WellBeing for People, (4),Quality Education, (5)Gender Equality, (6)Clean Water and Sanitation, (7)Affordable and Clean Energy, (8)Decent Work and Economic Growth, (9)Industry, Innovation, and Infrastructure, (10)Reducing Inequalities, (11)Sustainable Cities and Communities, (12) Responsible Consumption and Production, (13)Climate Action, (14) Life Below Water, (15) Life on Land, (16)Peace, Justice and Strong Institutions, and (17)Partnerships for the Goals

A critical examination of all the goals which the agenda desires to achieve would reveal that the issues involved affect the African countries, including Nigeria, more than the rest of the world. For instance, each of the 17 goals is a critical issue which the government of Nigeria has been grappling with since its political independence. Unfortunately, the Nigerian situation has been compounded in recent years, by the Boko Haram insurgency which has been plaguing the nation since 2009. Terrorist attacks by the insurgent group in the Northeastern Nigeria, have consistently devastated the economic and social infrastructure in a region which, prior to insurgency, was already experiencing acute socio-economic backwardness and high poverty index.

The initial counter insurgency response of the government which was the use of brutal force by the military aggravated rather than abated the spate of attacks. But as from 2015, the military started to record some break-through as they rolled -back the initial success of the terrorist group and recaptured most of the enclaves which were formerly under their control. This is the reason why the Nigerian government consistently claim that Boko Haram has been technically defeated.

However, the fact that;

- the insurgents continue with their terror attacks through guerilla warfare tactic,

- about 130 abducted Chibok girls in 2014 are still being held hostage by the sect,

- the insurgents had an easy ride to Daptchi town where they abducted another 110 school girls in March 2018,

- some internally displaced people have refused to go back to their homes due to security challenges, and
- the dreaded Sambisa forest (where the insurgent abductees are being held hostage) is still under the control of the insurgent group, are enough reasons to say that war against terror is far from being over in Nigeria.

Suffice it to say too that over the past nine years,Boko Haram insurgency has deprived people of their sources of livelihood, worsened poverty and hunger, robbed people of access to good health and education, clean water and sanitation, destroyed peace, increased inequality and injustice and weakened institutions among other effects. Undoubtedly, these are a clear evidence that insurgency can hinder the achievement of the SDGs. The main objective of this research therefore is to explore a comprehensive or holistic counter-insurgency approach that would completely eradicate insurgency or atleast, reduce it to the barest minimum and pave the way for the achievement of the SDGs in Nigeria. The study used counterterrorism and counterinsurgency interchangeably.

Boko Haram Insurgency.

The Boko Haram terrorist group, whose original name is Jama'atu Ahl al-Sunnah li Dawah wa-l-jihad, (which means "People committed to the ways of the Prophet Proselytization and Striving for Holy War) belongs to the Wahabi school of thought. The group believes in the primitive, immaculate and undiluted type of Islam. Since the pristine practice of Islam as they advocated it,could not be achieved in a community where Muslims and the adherents of other religious live together, they struggle for the creation of Islamic state or a caliphate where they could practice their own version of Islam. The sect rejects democracy, western education and other western values. Any kind of governance that is not based on sharia or Islamic doctrines is antithetical to them (Abdulazeez, 2016). The sect which was formed in 2002 came into global spotlight in 2009 when it commenced terror attacks following the extrajudicial killing of its founder, Mohamed Yusuf, by the Nigerian police (Bartolotta 2011).Since then, Nigeria has been a turbulent country and remained in the list of the countries that have to cope with terrorism. The insurgents started with attacks on soft targets and progressively included suicide bombing of strategic locations like the police headquarters in the Federal Capital Territory, the United Nations building, motor parks, mosques, churches and other public places (Sani 2011). Their tactic of operation also include kidnapping, sporadic shooting at gathered crowd, arson, bank robbery and looting of businesses (Schmidt, 2014). The state of emergency declared to curb insurgencyby the federal government in 
May 2013 in the three most affected states (Adamawa, Bornu and Yobe) and the human rights abuses which accompanied it escalated rather than abated their spate of attacks. The dastard operations of the terror group attracted more global attention following the kidnapping of about 276 school girls from a secondary school at Chibok, in 2014. The sect daringly created spheres of influence, including an 'Islamic State', under its control. Thousands of people were held hostage in the 50,000 square kilometers that fell under its power. This included military bases at Baga and Munguno and a police training school at Gwoza(BBC, 2015).The counter terrorism response of the government, which came in form of a robust military operation only started to yield some dividend in 2015 as the military commenced the roll-back of Boko Haram from most of the territories they occupied (Abdulazeez, 2016).

\section{THE NEXUS BETWEEN INSURGENCY AND THE SDGS}

\section{Loss of Economic Sustainability}

Aside the loss ofabout 20,000 lives, Boko Haram insurgency has led to unprecedented displacement of people. The violence unleashed by the insurgents were directed at civilian population. The population displacement led to the disruption of productive assets and economic infrastructure essential for livelihood. The economy of the Northeastern part of Nigeria depend majorly on agriculture. About $80 \%$ of the population engaged in farming, pastoralism and fishing (Abdulazeez, 2016). However, the population displacement affected the farmers who migrated from their place of origin due to security reason. This led to a drastic reduction in availability of food, loss of income, purchasing power and an increase in the prices of the few available food items, thereby causing a precarious situation of food insecurity. Agriculture production plummeted drastically between 2010 and 2015. According to a UNDP (2016) report, sorghum production declined by 82 percent, rice cultivation reduced by 67 per cent and millet farming went down by 55 per cent in Bornu state alone. The total loss in agricultural sector in the three most affected states due to Boko Haram insurgency amounted to 3.4 billion dollars. 64 percent of the losses occurred in Bornu state, 23 percent in Yobe state and 12 percent in Adamawa state (FGN, 2016).

Meanwhile, before insurgency, the region had been experiencing weak economic productivity compared to other regions in the country. As at 2010, poverty level in the region stood at 69 percent compared to the national poverty average of 60.9 percent (UNDP, 2016). Hence, the loss of livelihood/productive assets and inputs arising from displacement only exacerbated the preexisting poverty and hunger in the region. Putting all these together, one can say without mincing words that the achievement of SDGs numbers $1,2,5$, and 12 would be very difficult in the face of this precarious situation.

\section{Regional Economic Deterioration.}

Insurgency resulted in damages to road network, dis ruption of transportation, destruction of banks and market facilities. This significantly deteriorated micro-economic conditions of the region. For instance, $50 \%$ of the markets in the most affected states were either not functioning or intermittently functioning. Apart from these, the disruption of essential social services like electricity and water supply further deteriorated the already parlous situation of the region. According to World Bank estimates, the economic losses suffered by the six affected states between 2011 and 2015 amounted to US\$ 8.3 billion or 1.66 trillion naira (UNDP, 2017). Experts predict that it would take the government several years to replace some of the vandalized infrastructure in that part of Nigeria. This drawback would undoubtedly hamper any progress on achieving SDGs numbers 5, 9 and 11 especially as insurgent attacks continues unabated.

\section{Poor Living/Health Condition}

Furthermore, the displaced people lack access to minimum nutritional requirement, good sanitary condition, and clean water. As at 2016, an estimated 1. 2 million children (under 5 years) and lactating women were experiencing severe malnutrition, 1.6 million people lacked access to basic sanitation while about 3.6 million people were denied access to clean water. More so, almost 6.2 million people lived without proper hygiene (UNDP, 2017).The condition is more critical in IDP camps (formal and informal) which have high concentration of people and lack adequate health services, as well as the host communities whose lean facilities were overstretched. This made the people vulnerable to different types of communicable diseases.

The health condition is made more precarious due to the deliberate targeting and destruction of health facilities and equipment by the insurgents. According to Obi and Eboreime (2017) Boko Haram insurgents destroyed about 788 health facilities and killed many health workers in the region. In Borno state alone, about 48 health workers were killed and over 250 injured by the insurgents. The state also lost about 40 percent of its medical facilities while only 50 percent of the remaining ones were functional. Invariably, Bornu state suffered from high attrition rate of health workers as it lost 35 percent of its medical doctors to other 
states (Obi and Eboreime, 2017). These happened in a region which had the worst health indices, marked by shortage of skilled health workers and inadequate health facilitieseven before the outbreak of insurgency. This parlous health scenario would make the achievement of SDGs numbers 3 and 6 difficult if not impossible.

\section{Education}

Quality education is unarguably one of the sustainable development goals targeted to be achieved by 2030 . Education constitutes a veritable key to the national development of every nation. However, quality education can only be given and/or received in a safe, secured, violent free teaching and learning environment. Unfortunately, Boko Haram insurgency has inhibited the educational growth of the area regarded as 'Educationally Disadvantaged Area' and pulled it backward by almost 15 years. The insurgents constantly raided, destroyed and burnt many primary and secondary schools and engaged in suicide bombing at tertiary institutions in the region. These, coupled with the abduction of about 276 girls at Chibok in 2014 and over 110 girls at Daptchi in 2018, made schools unsafe for the children that were being persuaded to show interest in western education before insurgency. The repeated attacks on school infrastructure and the use of some school facilities as IDP camps left about 2.9 million children without access to education in the region. Undoubtedly, achieving SDG 4 would be a mirage in this kind of situation.

The analysis above has revealed that before Nigeria could achieve the SDGs, a very carefully designed strategy which will be potent in permanently arresting the menace of terrorism must be put in place. This is what is referred to as Sustainable Counter-insurgency.

Nigerian Government Counter-insurgency Approach So Far

Up until 2014, the only counter-insurgency strategy adopted by the Federal Republic of Nigeria was military-centric which centered mainly on 'meeting force with force'. This approach proved ineffective asthe military and members of the Joint Task Force (JTF)were accused of gross violation of fundamental Human Rights and extra-judicial killing of the apprehended Boko Haram suspects in the course of the counter-terrorism operations. In October, 2013, the Amnesty International reported that nearly 1,000 people died in military custody in the first half of the year (Amnesty International, 2013). Hence, rather than countering terrorism, the method of meeting force with force ignited the flame of terrorism as the country witnessed intense rounds of suicide bombings and hostage taking which increased the number of deaths markedly in Nigeria. This rendered the initial counter-terrorism strategy counterproductive.

The drawback of this strategy encouraged the Federal Government of Nigeria to adopt a more holistic and softer approach to combating terrorism. In March, 2014, the government established the National Counter Terrorism Strategy (NACTEST) based on the principles of Effectiveness, Proportion, Transparency, Flexibility, and Collaboration (Mbagwu, 2017). In 2016, the leadership of President Muhammadu Buhari, the incumbent President of Nigeria, reviewed the NACTEST(Momoh, 2017). The 2016 revised NACTEST was organized around five streams of activities aimed at effective counter-terrorism. These areto forestall, secure, identify, prepare and implement with key objectives and indicators to effectively ensure monitoring and evaluating successes at each stage.(Yushau,2016)

(a) The 'Forestall' strand is about tackling radicalization of individuals and emphasizing security awareness among the populace

(b) 'Secure' stream is concerned with safeguarding citizens and infrastructures by reducing their vulnerability to attacks.

(c) 'Identify' objective deals with stopping terrorist threats and attacks on Nigeria and her interest

(d) 'Prepare' strand involves ensuring that the nation is ready to manage and minimize the consequences of terrorist attack

(e) 'Implement' stream has to do with the cooperative of all levels, both the public and private sectors, including civil society organisations. It states the involvement of Ministries, Departments and Agencies (MDAs) and other stakeholder organisations in executing their assigned roles and statutory responsibilities, under the coordination of the Office of the National Security Adviser (ONSA, 2016).

As fantastic as the revised strategy appears to be, studies still reveal that the Nigerian government continues to rely mainly on the use of military force to combat the insurgent group and that is why the counter-insurgency method has not recorded huge success. The little success achieved through the strategy has made the Nigerian government to claim times and over again that Boko Haram has been technically defeated and its coordinating force decimated.But the reality on ground shows that Boko Haram has not been annihilated. Through guerilla warfare tactic, the group continues to carry out intermittent attacks and suicide bombing of strategic locations and IDP camps with fatal causality, even among the military. A report 
released by Amnesty international in 2017 indicated that no fewer than 375 civilians were killed in various terror attacks by Boko Haram sect between January and November 2017 alone(Amnesty International, 2017). More so, the various coordinated attacks carried out by the sect only in the first half of 2018 has led to the death of over 150 people.This included the 3 United Nations Aid workers which were killed in suicide bomb attack at IDP camp at Rann in Bornu state. All these, coupled with the adoption of another 110 school girls at Dapchi in March 2018, and the sect daring attacks on military formations show that NACTEST is still fraught with some gaps that question its potency as a policy document that could guarantee sustainable counterinsurgency in Nigeria.

\section{Achieving Sustainable Counter-insurgency.}

Sustainable counter-terrorism can be described as a holistic counter-terrorism strategy that includes military, political and socio-economic measures adopted by a state in response to the outbreak of insurgency. It involves a mixture of offensive, defensive and stability operations, conducted along multiple lines, with minimum collateral damage, in order to guarantee a society free from tension/ apprehension of insurgency or at least reduce insurgency to the barest minimum.

The contemporary international politics does not view security narrowly in terms of the survival of the state, rather, it also encompasses issues that center on socioeconomic emancipation as well as political inclusiveness such as improved governance, political responsiveness to the citizens needs and international cooperation. This made Peoples and Williams (2015) opine that addressing the security of a nation involves a multidisciplinary approach in explaining what is wrong with the current social reality, identifying the actors to change it and providing clear norms and achievable practical goals for social transformation.

The first step in this direction is identifying the factors that encourage terrorism. As a matter of fact, the first pillar of the Global Strategy for combating terrorism postulates that member states shall commit themselves to addressing conditions that are conducive to the spread of terrorism by engaging in and supporting activities to help prevent radicalization, violent extremism and ultimately terrorism. Some researchers of the situation in Northeastern Nigeria have identified some factors which made the region a fertile ground for insurgency as extreme poverty and hunger, religious extremism, deep-rooted feelings of socioeconomic marginalization, lack of political openness, violation of human rights, inability of the government to manage tension and conflict, socio-economic disparity, limited state presence which often leads to low rate of economic growth, low human capital development, low access to education and low investment in economic infrastructure. In line with this first pillar therefore, the ongoing military action against terrorism must be accompanied by a genuine effort and feasible plans to address the root causes of terrorism as listed above.

As stated earlier, poverty is unarguably one of the issues that make people vulnerable to recruitment into insurgency in Northeastern Nigeria. Hence, any effort aimed at achieving sustainable counter-insurgency must include a feasible programme that would transform the economy of the region, engender economic growth and development and ultimately alleviate poverty. The government effort towards making the region to recover and stabilize may be channeled towards the area where the region has comparative advantage which is agricultural sector. A significant investment in economic infrastructure, particularly in farming may include disbursing of grants or soft loan to farmers, making farm inputs available and affordable to them, and creating market for their products by encouraging consumption of local products. These would increase the level of production, generate more employment and deal decisively with poverty.

Investment in economic infrastructure also involves gearing up private sector development as well as diversification of them no-cultural economy of the region. Both the government and the humanitarian agencies working in the Northeast Nigeria presently could establish vocational centers and encourage young men and women to go into the craft of their choices. Grant or soft loan could be made available to them as take-off capital after their training. The fact that the economy of the region has suffered from neglect over the years makes this imperative. The commitment of the government (both state and federal),to the project of eradication of poverty and promotion of sustainable economic growth would bring about prosperity in the region and undoubtedly reduce their vulnerability to recruitment as terrorists.

Furthermore, reclaiming the region from the scourge of insurgency involves raising the public capital expenditures there for the purpose of investment on local social services such as good road network, water, health, electricity and recreation centers. Unemployment and lack of access to the amenities that make life pleasant and enjoyable may make peopleto attach little value to life. That is part of the reasons that make insurgency/suicide bombing thrive. But the availability of social amenities could make them to see life from another perspective and attach more value to it. 
Although, some scholars disagree with the view that poverty is a predisposing factor to insurgency. They back up their argument by citing some societies where people go through acute poverty without experiencing insurgency. However, one fact that cannot be disputed is that poverty ridden people are always ready to listen to anyone who can satisfy their basic requirement of food need or means of livelihood. This lacuna is usually explored by religious bigots to rally people, hoodwink them and tell them what they want them to hear or do (Quiggin, 2009). Mohamed Yusuf, the founder of Boko Haram sect, established a charity organization through which he catered for the needs of the vulnerable. That was how he got a large followers with which he started the insurgency. Therefore, a genuine effort at achieving sustainable counter-insurgency cannot dismiss the promotion of sustainable economic and social growth with a wave of the hand.

Furthermore, religiosity is a way of life in Nigeria. Most Nigerians, either Christians or Muslims consider religion more important to them than their ethnic identity. Hence, anything that religion is used to justify gets more attraction. That is why sustainable counter-insurgency effort must not handle the issue of religious intolerance/bigotry with a kid glove. The government needs to work with the religious leaders to de-radicalize the religious fanatics (Adeyemi, 2015). Since both Muslims and Christiansclaim that their religions preach peace and not abhorrence and viciousness, this claim should reflect and be more pronounced in the preaching of the religious leaders and the attitudes of the followers as well.(Okai,2017). In addition, the government can constantly promote religious tolerance, respect for all religious values, beliefs and cultures of other faith as well as intra-faith and inter-faith dialogue.

Moreover, the governments of the country and the respective states need to initiate programmes that would regularly promote a culture of peaceful co-existence, dialogue and ethnic tolerance between the various ethnic nationalities in the Northeastern region and in the country at large. Regular education and public awareness could be organised by the relevant government agency such as the National Orientation Agency (NOA). The agency can work to identify any source of tension and prevent them from snowballing into conflict. It can also address issues of intercommoned grievances and disputes that may have arisen as a result of population displacement and the struggle for livelihood either in the IDP camps or host communities.

A genuine peacebuilding mechanism that involves inclusive growth will encourage the people to repose confidence in the government and its ability to adequately address grievances. Hence, rather than take laws into their hands, they will always be willing to surrender any conflict to the necessary agency established by the government for the purpose of conflict resolution. Furthermore, NOA canidentify signs of radicalization early and mount an early warning machinery. It can also encourage mothers, who are regarded as nurturers of life and community guardians to play their roles effectively, so as to be able to detect early warning signs of radicalization in their children and thereby prevent them from being recruited into terrorist group (Iles anmi, 2017).

A corollary to this is the effort that would encourage community security initiative. Although, the constitution of Nigeria does not allow the establishment of state police, nevertheless the existing "Civilian Joint Task Force" (voluntary civilians assisting in the task of policing the troubled communities in the Northeastern region) could be further empowered to assist the conventional security agencies in community security watch and provision of necessary information that could lead to early detection of any tendency towards insurgency (Cilliers, 2017).

A feeling of political exclusion, marginalization or sheer government neglect constitute part of the factors that encourage insurgency. Hence, a move towards ensuring sustainable counter-insurgency should take the issue of inclusive governance and accountability with all seriousness. This is very important in a country like Nigeria where there are about 400 ethnic groups. Decision making process on any social, political or economic issue should be very transparent and all embracing (Pizzuto, 2016). The people will be ready to assist the government in ensuring a peaceful society if they see transparency in the conduct of government business or feel included in the government policy formulation and implementation.

Education is very central to any plan that will guarantee sustainable counter-terrorism. Education liberates people from mental slavery and the clutches of religious bigots and political demagogue. The religious extremists themselves are not unaware of this and that is why they intensified their effort to destroy educational facilities in Northeastern Nigeria.

Lack of access to education would lead to an increase in the population of street urchins (popularly called Almajiris in Nigeria) from whom the insurgents could get new recruits.The Almajiri system keeps people out of western education and make them available for the dogmatic teachings of the Islamic fundamentalists and through that, they could be recruited to insurgency. Therefore, the 
government should make concerted efforts, including seeking external assistance, to rebuild the school facilities that have been destroyed by insurgency and to encourage pupils/students to return to school (Abdulrasheed, 2015). In addition, given the fact that the destruction of school facilities, coupled with the abduction of students from their schools have worsened the existing lack of interest in education among the Almajiris in the region, the governments (both at federal and state levels)are encouraged to continue to evolve realistic initiativesto enlist the interest of the Almajiris in western education. The method of withdrawing them from the streets completely and suddenly too, and confining them to a particular place in order to give them access to western education may not be effective at the initial stage. The reason for this is that the Almajiris are not used to staying permanently in a particular location. Instead of taking them off the street at once and keeping them in school for many hours, a two hours' class may be specially designed for them initially, with one meal after class. The classes may be fixed for the morning or evening period. The number of hours they spend in school may increase as they show more interest in learning.The government of Nigeria may seek collaboration with UNESCO in doing this.

Further to this, getting the youth engaged in useful activities is one of the genuine steps which the government can take towards achieving sustainable counter-terrorism. Recruitment into insurgency is mostly done with the young people because they are susceptible to terrorist narratives. Recruiters cash in upon their idleness, discontents, grievances and sometimes gullibility to manipulate them and suggest another platform through which they can vent their grievances against the government. That is why the government needs to engage with them on their terms, through getting them involved in conversations that would enable them express themselves and allowing them to participate in decision making system (Guterres, 2018). Time and resources can be invested to empower them and to counter the manipulative messages which they have received. Political inclusion and regular dialogue with them would provide the government the necessary platform to help them to grow to become responsible citizens that would be prepared to defend the course and interest of the nation rather than join any terrorist group to bring the nation down.

Moreover, the government also needs to establish a workable and reliable system of assisting the victims of terrorism and their families to stabilize and return to normalcy. Although there is National Emergency Agency
(NEMA) and its state counterpart which is, State Emergency Agency (SEMA) whose main mandate is to attend to the needs of the displaced people among other things. But the agencies are doing very little due to paucity of funds. In most cases, their intervention does not go beyond the provision of relief materials and occasional distribution of food items to the displaced people. The displaced people, some of whom lost their property and the bread winners of their families certainly need more than this to return to normal life. Sule and Bangaje,(2017) posit that no one can talk of sustainable counter-terroris $m$ when the victims of insurgency are not properly rehabilitated This is because despondency, anger and poverty may drive them into the waiting hands of the terrorists as new terror recruits.In this regard, the government needs to seek the assistance of the United Nations Agencies and some popular aid agencies to help in the rehabilitation of the people affected by terrorism, including the rebuilding of the damaged infrastructure.

Capacity building is also a very potent counter-terrorism mechanismwhich Nigeria should look into. It helps the government to develop the state capacity to get accurate and timely information that would be useful in preventing and combating terrorism.This is closely linked with the ability of the state to effectively deploy technology/intelligence in the fight against terrorism. As a matter of fact, military force has increasingly proved ineffective against violent transnational terrorist groups. Rather, intelligence and communications are more central to fighting a sustainable counterterrorism than a country's military capabilities (Kegley and Blanton, 2011).Intelligence gathering can help to detect the operations of the insurgents such as their method of recruitments, training camp, installations, source of weapon procurement, and foil their plans of attacks before they are carried out. Intelligence gathering also helps in detecting the finances and financiers of terrorist organisations. A proper deployment of intelligence gathering would leave the terrorists with no hiding place andeventually cripple their activities. Nigeria may seek the assistance of the United States Bureau of Counterterrorism on this. The Bureau Anti-Terrorism Assistance (ATA) covers; prevention of terrorist attacks, responding to and mitigating terrorist attacks, border security, provision of equipment relevant to investigations and some other services to partner nations in order to build their capacities.

Similarly, in view of the fact that terrorism is a global issue, no state can successfully combat it, acting alone.Sustainable counter-terrorism requires the government to step-up efforts at forging cooperation at sub-regional, regional and 
international levels. Co-operation is necessary to improve border and customs controls so as to prevent and detect the movement of terrorists. It will also assist states to prevent and detect the illicit traffic in, small arms and light weapons, conventional ammunition and explosives, which are the weapons being used by Boko Haram terrorist group. Moreover, cooperation with other states will enable Nigeria to explore the advantage of the framework provided by relevant international, regional and sub-regional organizations to share best practices in counter-terrorism capacity-building like the one discussed above. Furthermore, international cooperation would encourage regular formal and informal meetings that would enhance frequent exchanges of information on cooperation and technical assistance among member states and the United Nations bodies dealing with counter terrorism as well as other relevant specialized agencies. Cooperation would also make available the type of assistance that can be gotten at each level.

\section{CONCLUSION}

Nigeria is one of the countries that subscribe to the Sustainable Development Goals. However, the terrorist insurgency which the country has been grappling with forthe past nine years has been constituting a serious threat to the achievement of the SDGs. Insurgency has damaged the fabric of socio-economic structure of the Northeastern region thereby drawing the clock of development in the region many years backward, making it to be farther away from the realization of the SDGs.But as the tempo of terror attack is going down, several efforts are being made by both governmental and non-governmental organisations to assist the Nigerian government in rebuilding the battered socioeconomic structure, particularly of the three most affected states in the region. However, for the various intervention activities to pay up and for the country to be on the track of achieving the SDGs, Nigeria must proffer a lasting solution to the menace of insurgency.Otherwise, any progress recorded on the path of recovery or achieving the SDGs may be brought to nothingness, particularly as occasional terrorist attacks continue unabated. It is on this basis that this research would conclude by saying that sustainable counter-terrorism is sine qua non to the achievement ofSustainable Development Goals in Nigeria. The study has extensively discussed the factors that can engender sustainable counter-insurgency such as unalloyed commitment to the overall development of the northeastern region, including making genuine effort at reducing poverty, making jobs available to the teeming youth there, stemming the tide of religious extremism, embracing the use of intelligence in counter-insurgency effort, also embracing transparency and accountability in conducting government business at local, state and national levels, and forging cooperation with other nations and relevant counterterrorist agencies at regional and international levels.

\section{REFERENCES}

[1] Abdulazeez, M. (2016), The Boko Haram Insurgency and Internal Displacement. State Secretariat for Migration (SEM) Zurich.

[2] Abdulrasheed, O. (2015), Effects of Insurgency on Girls' Education in North Eastern Nigeria,.European Center for Research, Training and Development. UK www.eajournal.org

[3] Adeyemi S. (2015). Help De-radicalise the North-east, Ensure Peace Nationwide. Minister Urges Religious Leaders. http://www.nta,ng/news/2051210-helpderadicalise-the-north-east-ensure-peace-nationwideminister-urges-religious-leaders/ (Retreived 07 May, 2018)

[4] Amnesty International (2013), Nigeria: Death of hundreds of Boko Haram Suspects in Custody Requires Investigation

https://www.amnesty.org/en/latest/news/2013/10/niger ia-deaths-hundreds-boko-haram-s us pects-custodyrequires-investigation/Retrieved 08 May, 2018

[5] Amnesty International (2018)Nigeria2017/2018 https://www.amnesty.org/en/countries/africa/nigeria/re port-nigeria. Retrieved 15 June, 2018

[6] Barnes E. Julian (2015) Boko Haram has Lost Territories in Nigeria. The Wall Street Journalhttps://www.wsj.com/europe

[7] Bartolotta Christopher (2011), Terrorism in Nigeria: The Rise of Boko Haram. The Whitehead Journal of Dplomacy and International Relations Vol 5, No 2

[8] BBC News (2015) Boko Haram Pledges Allegiance to Islamic State, www.bbcnews.comRetrieved 09 May, 2018.

[9] Cilliers J. (2017), What Drives Instability in Africa and What Can Be Done About It. University of Pretoria Conversation Africa Inc.

[10] Federal Government of Nigeria. North-East Nigeria Recovery and Peacebuilding Assessment: Volume II Component Report. 2015

[11] Guterres A. (2018) Investing in the Youth to Counter Terrorism: A Remark https://www.norway.no/en/mis sions/un/events/investin g-in-youth Retrieved 18 May, 2018 
[12] Ilesanmi O.A (2017) “Women's Roles in Development and Peacebuilding in Africa", In Sotunsa M.E and Yacob-Haliso O (ed) Gender, Culture and Development in Africa. Texas, PanAfrican University Press.

[13] Kegley Jr. C.W. and Blanton S.L. (2011), World Politics, Trends and Transformations. Boston, Wadsworth Cengage Learning.

[14] Mbagwu, J. (2017). Beyond Military Force as Strategy for Countering Terrorism in Nigeria: A Handbook. Lagos: Olive Branch

[15] Momoh, E. (2017). Implementing National CounterTerrorism Strategy.Aitonline.tv/post-implementingthe-national-counter-terrorism-strategy. Retrieved 16 May, 2018.

[16] Obi, F. A. and Eboreime E. (2017), How Boko Haram is Diverstating Health Services in North East Nigeria. Johannesburg, University of Witwaters rand,

[17] Office of the National Security Adviser, Federal Republic of Nigeria (2016) The National Counterterrorism Strategy, 2016 Revised. Krextresource.co /ctc /NACTEST. Retrieved on 30 July 2018

[18] Okai, M.O. (2017), “ Religion, Insurgency and Gender-based Violence in Africa: The Case of Nigerian Boko Haram" In Sotunsa M.E and YacobHaliso O (ed) Gender, Culture and Development in Africa. Texas, Pan-African University Press

[19] Peoples, C. and William, N. (2015) Critical Security Studies: An Introduction. New York: Routledge

[20] Pizzuto, M. (2016), Alter-Messaging: The Credible Sustainable Counter-terrorism Strategy Cooperation. Center on Global Counterterrorism,www.globalct.org

[21] Quiggin T. (2009), Understanding al-Qaeda's ideology for Counter-Narrative.Work Perspective on Terrorism 3 , No 2.

[22] Schmidt Eric (2014) School Girls taken by Boko Haram Still Missing. New York Times, August. Retrieved June 20, 2016.

[23] Shehu S. (2011) "Boko Haram: History, Ideas and Revolt" inthe Journal of Constitutional Development. Center for Constitutionalism and demilitarisaton.

[24] Sule A. and Bangaje A. S. (2017) An Assessment of the Performance of United Nations Children Fund UNICEF) in Bornu State, Nigeria. Journal of Public Administration and Social Welfare Research, Vol 2, No 2, ISSN 25043597 www.iiardpub.org
[25] United Nations Organisations (2015), Sustainable development Knowledge Platform: The 2030 Agenda for Sustainable Development. UNO Official Document

[26] United Nations Development Programme (2016). North East Nigeria Livelihoods and Economic Recovery Assessment, May

[27] United Nations Secretary General (2016), "SecretaryGeneral's remarks to the press at COP22". UN. 15 November 2016. Retrieved 16 June, 2018.

[28] Yushau, A. (2016). NACTEST: Osinbajo and the Revised Counter- Insurgency Campaign. Retrieved from: $\quad$ https://www.Yashuaib.com/2016/09/nactestosinbajo-and-the-revised-counter-insurgencycampaign 